\title{
Mabberley's scholarship
}

\author{
M.F. Large \\ School of Environmental \& Animal Sciences, \\ Unitec, Auckland 1025, New Zealand \\ marklarge@orcon.net.nz
}

\begin{abstract}
David Mabberley's distinguished and productive academic and administrative positions, roles, honours, books and other publications are given.

Keywords. Awards, Cambridge, eponymy, Kew, Leiden, Oxford, Plant-book, Seattle, Sydney, Wadham College
\end{abstract}

\section{The flow of books}

David Mabberley's first book was a volume of papers dedicated to E.J.H. Corner on his 70th birthday, which he edited jointly with the late Chang Kiaw Lan (1927-2003), also one of Corner's students at Cambridge. There followed, in 1981, a volume of reprinted essays by Arthur Harry Church, who had inspired Corner from early on, and, two years later, the first edition of the tertiary level text-book Tropical rain forest ecology. Two more years elapsed before the highly acclaimed Jupiter botanicus, a biography of Robert Brown, marking the first of David's substantial contributions to the history of botanical science. In 1987, came the first edition of a book for which he is now, of course, famous world-wide: The Plant-book - the 706 page dictionary of vascular plants. Data and cross references for this dictionary were originally kept on cards and the manuscript was typed, as Anne Sing recalls in this volume. It is noteworthy that at this point, David had not yet turned forty.

The Plant-book (eventually to become Mabberley's plant-book in 2008, and now in its fourth edition) has a reappearing role in David's output, where interludes between editions have seen the appearance of volumes such as: An exquisite eye: The Australian flora and fauna drawings 1801-1820 of Ferdinand Bauer (with Jo Anne Pomfrett, and Peter Watts); The Flora Graeca story. Sibthorp, Bauer and Hawkins in the Levant, (first author Hans Walter Lack); Paradisus: Hawaiian plant watercolors by Geraldine King Tam; Ferdinand Bauer: the nature of discovery; Arthur Harry Church: the anatomy of flowers, The story of the apple (with Barry Juniper); and in 2017, the momentous Joseph Banks' Florilegium: Botanical treasures from Cook's first voyage (with Mel Gooding and Joe Studholme). The latter was followed by 'Painting by numbers' - the life and art of Ferdinand Bauer; soon to be followed by The extraordinary story of the apple (again with Barry Juniper); The Robert Brown handbook: a guide to the life and work of Robert Brown (1773-1858), Scottish Botanist; and Botanical revelation: preDarwinian European encounters with the Australian flora, all of which are in press and due in publication this year. A full listing of David's twenty-three books appears below, separate from the list of his other publications. 


\section{Current positions and roles}

Currently David Mabberley is Emeritus Professor, Faculty of Science, University of Leiden, The Netherlands (from 2019); Emeritus Fellow, Wadham College, University of Oxford, UK (from 2014); Honorary Fellow, National Botanic Garden of Wales (from 2018; where the David Mabberley Archive is deposited); Adjunct Professor, Macquarie University, Sydney (from 2015); Director, David Mabberley Consulting (since 1996); Honorary Research Associate, Royal Botanic Gardens Sydney (since 1996); Chairman, General Committee on Botanical Nomenclature, International Association for Plant Taxonomy (since 2010); corresponding member, Nomenclature and Taxonomy Advisory Group, Royal Horticultural Society (since 2014); Member, Angiosperm Phylogeny Group (since 2015).

\section{Past positions held}

Before retirement, David Mabberley was Executive Director, Royal Botanic Gardens \& Domain Trust, NSW, Australia, i.e. the Royal Botanic Garden \& Domain (Sydney), the National Herbarium of NSW, the Australian Botanic Garden (Mt Annan) \& the Blue Mountains Botanic Garden (Mt Tomah) (2011-2013); Keeper of the Herbarium, Library, Art and Archives, Royal Botanic Gardens Kew, Richmond, Surrey, UK (2008-2011); Extraordinary Professor, Faculty of Science, University of Leiden, The Netherlands (2004-2018); Visiting Professor, Department of Plant Sciences, University of Oxford (2008-2011); Director of the University of Washington Botanic Gardens, Orin and Althea Soest Professor of Horticultural Science, and Professor of Economic Botany, College of Forest Resources, University of Washington, Seattle, USA (appointed 2004; 2005-2008); Adjunct Professor, College of Science, University of Western Sydney, NSW, Australia (2004-2010); Adjunct Professor, College of Arts and Sciences, University of Washington, Seattle, USA (2006-2008); Chief Executive Officer, Greening Australia (NSW) Inc. (1999-2001); Leidsuniversiteitsfonds Professor, University of Leiden, the Netherlands (1994-2004); Dean of Wadham College Oxford (1977-1982, 1991-1996); University Lecturer, Department of Plant Sciences, University of Oxford and Official Fellow and Tutor in Plant Sciences, Wadham College, Oxford (both 1976-1996); Keeper of the Gardens, Wadham College Oxford (1983-1996); Curator, Oxford University Herbaria (1992-1994); Senior Proctor, University of Oxford (1988-1989); Claridge Druce Junior Research Fellow in Taxonomy in Department of Plant Sciences and St John's College, Oxford (19731976).

\section{Past roles}

President, International Association for Plant Taxonomy (2005-2011; Past President 2011-2017; Honours Committee 2005-2017; and, from earlier, Council Member 
1999-2017 (leader for formulation of Strategic Plan); Trustee, Sir Joseph Banks Archive Trust, UK (1996-2015); Trustee, Bentham-Moxon Trust (2008-2011); Council Member, International Association for Cultivated Plant Taxonomy (20082011); Board Member, Ray Society (2008-2011); Member, Visiting Committee, Longwood Gardens, USA (2008-2014); Board Member, Flora Malesiana Foundation (2013-2019); Secretary (2005-2011), President (2011-2017) and proposer of both Shenzhen and Rio International Botanical Congresses, International Association of Botanical and Mycological Societies; Member, Nomenclature and Taxonomy Advisory Group, Royal Horticultural Society, UK (2008-2014); Sometime member of the Boards of Ashmolean Museum, Botanic Garden, Bodleian Library, Faculty Board of Biological and Agricultural Sciences, Museum of the History of Science, Museum of Natural History, and Oxford University Press; President, Society for the History of Natural History (1993-1996); Chairman, Land Regeneration Foundation NSW, Australia (2001-2002); Member of Scientific Committee, International Dendrological Society (since 2003); Trustee, National Botanic Garden of Wales (2008-2011); Judge for Noma Awards for Publishing in Africa; Programs Selection Committee, American Public Gardens Association [APGA] (2005-2008); Member, Directors of Large Gardens, APGA (2005-2008); External Examiner in Botany, University of Peradeniya, Sri Lanka and University of Newcastle, NSW; Board Member, Pacific Northwest Horticultural Trust (Seattle; 2005-2008); Council Member, Ray Society (UK; 2008-2011); Patron, Cactus \& Succulent Society of NSW (2011-2013); Director, Council of Heads of Australian Botanic Gardens Inc. (2011-2013); Member, Science Advisory Council, University of New South Wales, Sydney (2011-2013); Member, History Week Council, Sydney (2012-2013); Director, Foundation and Friends of the Botanic Gardens, Sydney (2011-2013); Sometime member of Executive Board, Nature Conservation Council (New South Wales) and Member, State Assessment Panel (NSW) of National Heritage Trust.

\section{A glittering cabinet of honours}

In the 2016 Australia Day Honours, David Mabberley was appointed a Member of the Order of Australia 'for significant service to horticultural science, particularly to plant taxonomy and tropical botany, as an academic, researcher and author'. Then, in 2018 , Macquarie University conferred upon him the degree of Doctor of Science (honoris causa) for his significant contribution to horticultural science (see Briggs \& Wilson in this volume). However, these are peaks in a long series of accolades. David's earlier awards include the Burbidge Medal 'for services to Australian plant systematics', from the Australian Systematic Botany Society in 2003; the Cuatrecasas Medal 'for excellence in tropical botany', from the Smithsonian Institution, USA in 2004; the Peter H. Raven Award 'for exceptional contributions to scientific outreach', from the American Society of Plant Taxonomists, USA in 2004; the Linnean Medal for Botany, from the Linnean Society of London, UK in 2006; Faculty Service Award, College of Forest Resources, University of Washington in 2007; the American Botanical 
Council's annual James A. Duke Excellence in Botanical Literature Award for 2008; the International Association of Plant Taxonomists' Engler Medal in Silver 2009 for publication of Mabberley's plant-book, 3rd edition in 2008; the Robert Allerton Award for Excellence in Tropical Botany, National Tropical Botanical Garden, USA in 2011; the American Botanical Council's annual James A. Duke Excellence in Botanical Literature Award for 2017 on publication of Joseph Banks' Florilegium; the John Thackray Medal for 2018 from the Society for the History of Natural History for Painting by numbers: the life and art of Ferdinand Bauer; and in 2019 the award of Excellence in Botanical Art and Illustration from The Council on Botanical and Horticultural Libraries, again for Joseph Banks'Florilegium. David is also a Life Member of the American Society of Plant Taxonomists.

Besides the aforementioned institutional recognition, botanical colleagues have named Senecio mabberleyi C.Jeffrey (Compositae; from the Ukaguru Mountains of Tanzania where David made significant, pioneering collections in 1970-1971 and 1972); Homalomena davidiana A.Hay (Araceae; New Guinea); Harpullia mabberleyana W.N.Takeuchi (Sapindaceae; New Guinea); and Grewia mabberleyana Phillipson et al. (Malvaceae; Madagascar). To these can now be added: Aglaia mabberleyi Pannell (Meliaceae; Borneo); Begonia mabberleyana D.C.Thomas \& Ardi (Begoniaceae; Sulawesi); Cinnamomum mabberleyi de Kok (Lauraceae; Indochina); and Keetia davidii Bridson \& Cheek (Rubiaceae; East Africa), all of which are published in this volume.

\section{Books}

1. Mabberley, D.J. \& Chang, K.L. (eds) (1977). Tropical botany. Essays presented to E.J.H. Corner for his seventieth birthday. Gard. Bull. Singapore 29. Singapore: Singapore Botanic Gardens.

2. Mabberley, D.J. (ed.) (1981). Revolutionary botany. Thalassiophyta and other essays of A.H. Church. xii +256 pp. with 28 tables. Oxford: Clarendon Press.

3. Mabberley, D.J.(1983). Tropical rain forest ecology. vii + 156 pp. with 18 figures. Glasgow: Blackie.

4. Mabberley, D.J. (1985). Jupiter botanicus. Robert Brown of the British Museum. 500 pp. with 64 text figures \& 24 colour plates. Braunschweig \& London: Cramer \& British Museum (Natural History).

5. Mabberley, D.J. (1987). The Plant-book. A portable dictionary of the higher plants. xii +706 pp. Cambridge: Cambridge University Press. [Reprinted with corrections in 1989, 1990, 1993 (twice), 1996]

6. Mabberley, D.J. (1992 ['1991']). Tropical rain forest ecology. $2^{\text {nd }} \mathrm{ed} . \mathrm{xi}+300 \mathrm{pp}$. Glasgow: Blackie. [Reprinted in 1994, 1998]

7. Mabberley, D.J. \& Placito, P.J. (1993). Algarve plants and landscape. Passing tradition and ecological change. xvi +300 pp. with 269 text figures \& 279 colour plates. Oxford: Oxford University Press 
8. Mabberley, D.J. (1997). The Plant-book. A portable dictionary of the vascular plants. $2^{\text {nd }}$ ed. xvi +858 pp. Cambridge: Cambridge University Press. [Reprinted with corrections in 1998, 2000, 2002, 2006; South Asian edition (different ISBN) in 2005]

9. Mabberley, D.J., Pomfrett, J. \& Watts, P. (1997). An exquisite eye: The Australian flora and fauna drawings 1801-1820 of Ferdinand Bauer. 167 pp. Glebe NSW: Historic Houses Trust of NSW.

10. Lack, H.W. \& Mabberley, D.J. (1998 '1999'). The Flora Graeca story. Sibthorp, Bauer and Hawkins in the Levant. xxxi +327 pp. Oxford: Oxford University Press.

11. Mabberley, D.J. (1999 '1998'). Paradisus: Hawaiian plant watercolors by Geraldine King Tam. viii + 152 pp. Honolulu: Honolulu Academy of Arts.

12. Mabberley, D.J. (1999). Ferdinand Bauer: the nature of discovery. 128 pp. with 32 text figures \& 63 colour plates. London: Merrell Holberton \& The Natural History Museum.

13. Mabberley, D.J. (2000). Arthur Harry Church: the anatomy of flowers. 128 pp. with 44 text figures \& 62 colour plates. London: Merrell \& The Natural History Museum.

14. Juniper, B.E. \& Mabberley, D.J. (2006). The story of the apple. 219 pp. with numerous text figures \& 36 colour plates. Portland, OR \& Cambridge, UK: Timber Press.

15. Mabberley, D.J. (2008). Mabberley's plant-book: a portable dictionary of plants, their classification and uses. $3^{\text {rd }} \mathrm{ed}$. xviii $+1021 \mathrm{pp}$. Cambridge: Cambridge University Press. [Reprinted with corrections in 2009, 2014].

16. Mabberley, D.J. \& de San Pío Aladrén, M.P. (2012). La carta de colores de Haenke de la Expedición Malaspina: un enigma - Haenke’s Malaspina colour-chart: an enigma. Facsimile + 36 pp. Madrid: Real Jardín Botánico, CSIC.

17. Mabberley, D.J. (2017). Mabberley's plant-book: a portable dictionary of plants, their classification and uses. $4^{\text {th }} \mathrm{ed}$. xxii $+1102 \mathrm{pp}$. Cambridge: Cambridge University Press. [Indian paperback edition in 2018]

18. Gooding, M., Mabberley, D.J. \& Studholme, J. (2017). Joseph Banks'Florilegium: Botanical treasures from Cook's first voyage. 320 pp. with 181 illustrations. London \& New York: Thames \& Hudson. [Also US \& Italian editions; English edition reprinted with corrections in 2018].

19. Mabberley, D.J. (2017). 'Painting by numbers' - the life and art of Ferdinand Bauer. $\mathrm{x}+246$ pp. Sydney NSW: NewSouth. [Reprinted with corrections in 2018]

20. Gooding, M., Mabberley, D.J. \& Studholme, J. (2019). Joseph Banks'Florilegium: Botanical treasures from Cook's first voyage. $2^{\text {nd }}$ ed. 320 pp. with 175 illustrations. London \& New York: Thames \& Hudson.

21. Mabberley, D.J. \& B.E. Juniper (2019 in press). The extraordinary story of the apple. Kew: Royal Botanic Gardens Kew. 
22. Mabberley, D.J., Moore, D.T. $\uparrow \&$ Wajer, J. (2019 in press). The Robert Brown handbook: a guide to the life and work of Robert Brown (1773-1858), Scottish botanist. Regnum Veg. 160. Glashütten: Koeltz Botanical Books.

23. Mabberley, D.J. (2019 in press). Botanical revelation: pre-Darwinian European encounters with the Australian flora. The Peter Crossing Library. Sydney NSW: NewSouth.

\section{Other publications}

(To July 2019, excluding reviews, popular articles, and reports)

1. Mabberley, D.J. (1970). Impatiens elegantissima. J. Roy. Hort. Soc. 95: 498-499, t.246.

2. Mabberley, D.J. (1971). Botanical aspects. In: Taylor P.J. (ed.) Oxford University expedition to the Cherangani Hills, Kenya, 1969, pp. 67-69. Bull. Oxf. Univ. Explor. Club 18: 54-86.

3. Mabberley, D.J. (1971). The Dendrosenecios of the Cherangani Hills. Kew Bull. 26: $33-36$.

4. Mabberley, D.J. (1971). Afro-alpines from the Cherangani Mountains. Q. Bull. alp. Gdn Soc. 39: 226-235.

5. Mabberley, D.J. (1972). More afro-alpines. Quart. Bull. Alp. Gard. Soc. 40: 142, 144-155, 161-162.

6. Mabberley, D.J. (1973). Evolution in the giant groundsels. Kew Bull. 28: 61-96.

7. Mabberley, D.J. (1974). Branching in pachycaul senecios: the Durian Theory and the evolution of angiospermous trees and herbs. New Phytol. 73: 967-975.

8. Mabberley, D.J. (1974). Pachycauly, vessel-elements, islands and the evolution of arborescence in "herbaceous" families. New Phytol. 73: 977-984.

9. Mabberley, D.J. (1974). The pachycaul lobelias of Africa and St. Helena. Kew Bull. 29: 535-584.

10. Mabberley, D.J. (1975). The giant lobelias: pachycauly, biogeography, ornithophily and Continental Drift. New Phytol. 74: 365-374.

11. Mabberley, D.J. (1975). Notes on the vegetation of the Cherangani Hills, N.W. Kenya. J. E. Africa Nat. Hist. Soc. 150: 1-11.

12. Mabberley, D.J. (1975). The giant lobelias: toxicity, inflorescence and treebuilding in the Campanulaceae. New Phytol. 75: 289-295.

13. Mabberley, D.J. (1975). The pachycaul Senecio species of St. Helena, "Cacalia paterna" and "Cacalia materna". Kew Bull. 30: 413-420.

14. Mabberley, D.J. (1977). E.J.H. Corner's botany. Gard. Bull. Singapore 29: 3-11.

15. Mabberley, D.J. (1977). The origin of the Afro-alpine pachycaul flora and its implications. Gard. Bull. Singapore 29: 41-55.

16. Hallé, F. \& Mabberley, D.J. (1977). Corner's architectural model. Gard. Bull. Singapore 29: 175-181.

17. Mabberley, D.J. (1977). Francis Hamilton's Commentaries with particular reference to Meliaceae. Taxon 26: 523-540. 
18. Mabberley, D.J. (1978). Annonaceae, Balanopaceae, Balanophoraceae, Canellaceae, Chrysobalanaceae, Crossosomataceae, Cynomoriaceae, Dichapetalaceae, Gentianaceae, Lentibulariaceae, Meliaceae, Nymphaeaceae, Podostemaceae, Sarcolaenaceae and Sphaerosepalaceae. In: Heywood, V.H. (ed.) Flowering plants of world, various pp. Oxford: Oxford University Press.

19. Mabberley, D.J. (1978). Herbaria of Allan Cunningham, Robert Heward and others at the Chelsea Physic Garden, London. Taxon 27: 489-491.

20. Mabberley, D.J. (1979). The Latin name of the "Padri" tree (Bignoniaceae). Taxon 27: 553.

21. Mabberley, D.J. (1979). The species of Chisocheton (Meliaceae). Bull. Brit. Mus. (Nat. Hist.), Bot. 6: 301-386.

22. Mabberley, D.J. (1979). Pachycaul plants and islands. In: Bramwell, D. (ed.) Plants and islands, pp. 259-277. London: Academic Press.

23. Mabberley, D.J. (1979). The Latin name of the "Ilapongu" tree (Dipterocarpaceae). Taxon 28: 587.

24. Mabberley, D.J. (1980). Edward and Sarah Bowdich's names of Macaronesian and African plants, with notes on those of Robert Brown. Botanica Macaronés 6: 53-66.

25. Mabberley, D.J. (1980). A re-examination of the 'Indian Catalogues' with particular reference to Hortus Malabaricus. In: Manilal, K.S. (ed.) The botany and history of Hortus malabaricus, pp. 80-110. New Delhi: Oxford \& I.B.H. Publishing.

26. Mabberley, D.J. (1980). Generic names published in Salisbury's reviews of Robert Brown's works. Taxon 29: 597-606.

27. Mabberley, D.J. (1981). Edward Nathaniel Bancroft's obscure botanical publications and his father's plant names. Taxon 30: 7-17.

28. Mabberley, D.J. (1981). Proposal to conserve Kohautia Cham. \& Schlecht. (1829, Rubiaceae) against Duvaucellia S. Bowd. (1825). Taxon 30: 335.

29. Mabberley, D.J. (1981). The name of the Madeiran Maytenus (Celastraceae). Taxon 30: 485-486.

30. Mabberley, D.J. (1981). G. Sheriff, Walter Stiles and E.F. Warburg. In: Williams, E.T. \& Nicholls, C.S. (eds) Dictionary of national biography, 1961-1970, various pp. Oxford: Oxford University Press.

31. Mabberley, D.J. (1981). Robert Brown of the British Museum: some ramifications. Soc. Bibliogr. Nat. Hist. Spec. Publ. 1: 101-109.

32. Mabberley, D.J. (1982). William Roxburgh's 'Botanical description of a new species of Swietenia (mahogany)' and other overlooked binomials in 36 vascular plant families. Taxon 31: 65-73.

33. Mabberley, D.J. (1982). On Dr. Carlquist's defence of paedomorphosis. New Phytol. 90: 751-755.

34. Mabberley, D.J. (1982). Notes on Malesian Meliaceae for 'The Tree Flora of Malaya'. Malaysian Forester 45: 448-455. 
35. Mabberley, D.J. (1982). 37 entries in Heywood, V.H. \& Chant, S.R. (eds) Popular encyclopedia of plants, various pp. Cambridge: Cambridge University Press.

36. Mabberley, D.J. (1983). The Dusty Miller's Tale, or Senecio cineraria DC restored. Watsonia 14: 279-280.

37. Mabberley, D.J. (1983). Dr Smith's Anemia, or, the prevention of later homonyms. Taxon 32: 79-87.

38. Mabberley, D.J. (1983). Meliaceae. In: Morley, B.D. \& Toelken, H.R. (eds) Flowering plants in Australia, pp. 198-200. NSW: Lansdowne Publishing Pty Ltd.

39. Mabberley, D.J. (1983) Corner, Edred John Henry. In: Bullock, A., Woodings, R.B. \& Cumming, J. (eds) The Fontana biographical companion to modern thought, pp. 158-159. London: Collins.

40. Mabberley, D.J. (1984). The optimistic in pursuit of the unrecognisable: a note on the origin of angiosperms. Taxon 33: 77-79.

41. Mabberley, D.J. (1984). Pallas's buckthorn and two and a half centuries of neglected binomials. Taxon 33: 433-444.

42. Mabberley, D.J. (1984). A monograph of Melia in Asia and the Pacific. The history of White Cedar and Persian Lilac. Gard. Bull. Singapore 37: 49-64.

43. Mabberley, D.J. (1985). William Theobald (1829-1900): unwitting nomenclatural reformer? Taxon 34: 152-156.

44. Mabberley, D.J. (1985). Die neuen Pflanzen von Ch. Huber frères \& Co., in Hyères. Taxon 34: 448-456.

45. Mabberley, D.J. (1985). 156 entries in Coe, M. (ed.) Oxford illustrated encyclopedia. Volume 2: The natural world. Oxford: Oxford University Press.

46. Mabberley, D.J. (1985). Florae Malesianae Praecursores LXVII, Meliaceae (diverse genera). Blumea 31: 129-152.

47. Heine, H. \& Mabberley, D.J. (1986). An Oxford waterlily. Kew Mag. 3: 167-175.

48. Mabberley, D.J. (1986). Meliaceae (excl. Aglaia). In: Whitmore, T.C. \& Tantra, I.G.M. (eds) Tree flora of Indonesia - Check list for Sumatra, pp. 148159. Bogor: FRDC.

49. Mabberley, D.J. (1986). Adaptive syndromes of the afroalpine species of Dendrosenecio. In: Vuilleumier, F. \& Monasterio, M. (eds) High altitude tropical biogeography, pp. 81-102. Oxford: Oxford University Press.

50. Mabberley, D.J. (1987). Robert Brown on Pterocymbium (Sterculiaceae). Arch. Nat. Hist. 13: 307-312.

51. Mabberley, D.J. (1987). A gamboge hoax? Kew Mag. 4: 201.

52. Mabberley, D.J. (1988). The living past: time [sic] state of tropical rain forest. In: Reynolds, E.R.C. \& Thompson, F.B. (eds) Forests, climate and hydrology: regional impacts, pp. 6-15. Tokyo: United Nations University.

53. Mabberley, D.J. (1988). Meliaceae. In: Morat, P. \& MacKee, H.S. (eds) Flore de la Nouvelle-Calédonie et Dépendances, vol. 15, pp. 17-89. Paris: Association de Botanique Tropicale. 
54. Mabberley, D.J. (1989). Meliaceae (excl. Aglaia). In: Whitmore, T.C, Tantra, I.G.M. \& Sutisna, U. (eds) Tree flora of Indonesia - Check list for Sulawesi, pp. 77-85. Bogor: FRDC.

55. Mabberley, D.J. (1989). Meliaceae (excl. Aglaia). In: Whitmore, T.C, Tantra, I.G.M. \& Sutisna, U. (eds) Tree flora of Indonesia - Check list for Bali, Nusa Tenggara and Timor, pp. 52-57. Bogor: FRDC.

56. Mabberley, D.J. (1989). Meliaceae (excl. Aglaia). In: Whitmore, T.C, Tantra, I.G.M. \& Sutisna, U. (eds) Tree flora of Indonesia - Check list for Maluku, pp. 70-76. Bogor: FRDC.

57. Mabberley, D.J. \& Beeston, A.F.L. (1989). Peter Begbie's “Non-Naturalist's Manual". Arch. Nat. Hist. 16: 285-287.

58. Mabberley, D.J. \& Pannell, C.M. (1989). Meliaceae. In: Ng, F.S.P. (ed.) Tree flora of Malaya, vol. IV, pp. 199-260. Harlow: Longmans

59. Mabberley, D.J. (1990a). Frits Jensen's Pacific plant collections. Kew Bull. 45: 199-204.

60. Mabberley, D.J. (1990b). The significance of the three independent 'Kew' editions of JOHNSON'S Gardener's Dictionary. Feddes Repert. 101: 55-68.

61. Mabberley, D.J. (1990c). Meliaceae (excl. Aglaia). In: Whitmore, T.C, Tantra, I.G.M. \& Sutisna, U. (eds) Tree flora of Indonesia - Check list for Kalimantan, part II. Bogor: FRDC.

62. Clark, T.P. \& Mabberley, D.J. (1991). Fruit anatomy in the Trichilieae (Meliaceae). Naturalia Monspel., Hors Sér. A7: 582-583.

63. Grierson, A.J.C. \& Mabberley, D.J. (1991). [Various genera,] Meliaceae. In: Grierson, A.J.C. \& Long, D. (eds) Flora of Bhutan, vol. 2, pp. 28-39. London: HMSO.

64. Hay, A. \& Mabberley, D.J. (1991). Transference of function and the origin of aroids: their significance in early angiosperm evolution. Bot. Jahrb. Syst. 113: 339-428.

65. Mabberley, D.J. (1991). The problem of 'older' names. In: Hawksworth, D.L. (ed.) Improving the stability of names: needs and options. Regnum Veg. 123, pp. 123-134. Königstein: Koeltz.

66. Singhakumara, B.M.P. \& Mabberley, D.J. (1991). Fruit abortion of Vitex altissima L.f. and V. leucoxylon L.f. (Verbenaceae). Naturalia Monspel., Hors Sér. A7: 662-663.

67. Mabberley, D.J. (1992). Robert Mudie (1777-1842) and Australian botany, or, the saga of the black bean. Austral. Syst. Bot. Soc. Newslett. 70: 13-15.

68. Mabberley, D.J. \& Cheek, M. (1992). The typification of Turraea L. (Meliaceae). Taxon 41: 541-545.

69. Mabberley, D.J. (1993). Ernest Henry Wilson. In: Nicholls, C.S. (ed.) Dictionary of national biography, missing persons, p.721. Oxford: Oxford University Press.

70. Mabberley, D.J. (1993). Architecture of Verbenaceae of Madang Province, Papua New Guinea, with preliminary notes on their reproductive biology. Sci. New Guinea 19: 37-45. 
71. Hay, A. \& Mabberley, D.J. (1994). On perception of plant morphology: some implications for phylogeny. In: Ingram, D.S. \& Hudson, A. (eds) Shape and form in plants and fungi. Linnean Society Symposium Series No. 16, pp. 101-117. London: Academic Press.

72. Higton, R.N. \& Mabberley, D.J. (1994). A willow gall from the galler's point of view. In: Williams, M.A.J. (ed) Plant galls - organisms, interactions, populations, pp. 301-312. Oxford: Clarendon Press.

73. Jenkins, R.M. \& Mabberley, D.J. (1994). A breadfruit among the dipterocarps: galls and atavism. In: Williams, M.A.J. (ed.) Plant galls - organisms, interactions and populations, pp. 183-199. Oxford: Clarendon Press.

74. Mabberley, D.J. (1994). Various contributions. In: Greuter, W., McNeill, J. \& Barrie, F.R., Report on botanical nomenclature - Yokohama 1993. Englera 14, pp. 98, 113-114, 132, 147, 153, 245. Berlin-Dahlem: Botanischer Garten und Botanisches Museum.

75. Mabberley, D.J. (1994). New species of Dysoxylum (Meliaceae). Blumea 38: 303-312.

76. Mabberley, D.J. (1994). The gardens. In: Davies, C.S.L. \& Garnett, J. (eds) Wadham College, pp. 100-121. London: Anness.

77. Mabberley, D.J. \& Hay, A. (1994). Homoeosis, canalization, decanalization, 'characters' and angiosperm origins. Edinburgh J. Bot. 51: 117-126.

78. Large, M.F. \& Mabberley, D.J. (1995). The pollen of Dysoxylum (Meliaceae): the demise of Pseudocarapa. Bot. J. Linn. Soc. 116: 1-12.

79. Mabberley, D.J. (1995). Wadham's new garden: Mallam Court. Wadham Coll. Gaz. III, 10: 61-63.

80. Mabberley, D.J. (1995). Meliaceae (excl. Aglaia). In: Dassanayake, M.D. (ed.) Revised handbook to the flora of Ceylon, vol. 9, pp. 229-300. Rotterdam: Balkema.

81. Mabberley, D.J. (1995). Vitaceae. In: Dassanayake, M.D. (ed.) Revised handbook to the flora of Ceylon, vol. 9, pp. 446-482. Rotterdam: Balkema.

82. Mabberley, D.J. (1995). The Oxford Botanical Museum and its fate. Oxford Plant Syst. 3: 15-16.

83. Mabberley, D.J., Pannell, C.M. \& Sing, A. (1995). Meliaceae. Flora Malesiana, ser 1, vol. 12(1), 407 pp. Leiden: Rijksherbarium.

84. Mabberley, D.J. (1995). Plants and prejudice. [Inaugural Oration as Professor]. Leiden: Rijksuniversiteit te Leiden.

85. Large, M.F. \& Mabberley, D.J. (1996). An assessment of pollen morphology in the genus Vitex (Labiatae). Grana 35: 291-299.

86. Mabberley, D.J. (1996). Sarah Bowdich, Margaret Gatty, Marie Stopes. In: Raphael, S. (ed.) Women and Natural History. Catalogue of the Exhibition in association with the Society for the History of Natural History, 1996, pp. 13-14, 15-16, 24-25. Oxford: Bodleian Library, University of Oxford.

87. Mabberley, D.J. (1996). Plant introduction and hybridization in colonial Australia: the work of John Carne Bidwill, Sydney's first Director. Telopea 6: $541-562$. 
88. Mabberley, D.J. (1996). Plants which bear seeds. In: Whitten, T. \& Whitten, J. (eds) Indonesian heritage encyclopaedia. Volume 4: Plants, pp. 26-27. Singapore: Didier Millet.

89. Mabberley, D.J. (1997). A classification for edible Citrus. Telopea 7: 167-172.

90. Mabberley, D.J. (1997). Meliaceae (excl Aglaia). In: Whitmore, T.C., Tatra, I.G.M. \& Sutisna, U. (eds) Tree Flora of Indonesia - Check list for Irian Jaya, pp. 169-181. Bogor: FRDC.

91. Steane, D.A., Scotland, R.W., Mabberley, D.J., Wagstaff, S.J., Reeves, P.A. \& Olmstead, R. (1997). Phylogenetic relationships of Clerodendrum s.l. (Lamiaceae) inferred from chloroplast DNA. Syst. Bot. 22: 229-243.

92. Mabberley, D.J. (1998). On Neorapinia (Vitex sensu lato, Labiatae-Viticoideae). Telopea 7: 311-315.

93. Mabberley, D.J. (1998). Australian Citreae with notes on other Aurantioideae (Rutaceae). Telopea 7: 333-344.

94. Mabberley, D.J. (1998). Notes on Australian Meliaceae. Telopea 8: 45-46.

95. Mabberley, D.J. (1998). Wilhelm Petermann and the Oriental Spruce. Thaiszia 8: $111-114$.

96. Mabberley, D.J. \& Steane, D.A. (1998). Rotheca (Lamiaceae) revived. Novon 8: 204-206.

97. Braggins, J.E., Large, M.F. \& Mabberley, D.J. (1999). Sexual arrangements in kohe-kohe (Dysoxylum spectabile, Meliaceae). Telopea 8: 315-324.

98. Capuron, R. \& Mabberley, D.J. (1999). Révision des Malvaceae-Grewioideae ('Tiliacées', p.p.) de Madagascar et des Comores. III. Les Grewia du sousgenre Vincentia (Benth.) Capuron. Adansonia sér. III, 21: 7-23.

99. Capuron, R. \& Mabberley, D.J. (1999). Révision des Malvaceae-Grewioideae ('Tiliacées', p.p.) de Madagascar et des Comores. IV. Les Grewia du sousgenre Burretia (Hochr.). Capuron. Adansonia sér. III, 21: 283-300.

100. Mabberley, D.J. (1999). Silene banksia (Caryophyllaceae), an ancient garden plant. Telopea 8: 249-256.

101. Mabberley, D.J. (1999). 'Robert Brown's' Parisian Podolepis (Compositae). Telopea 8: 297-298.

102. Mabberley, D.J. (1999). Robert Brown on Rafflesia. Blumea 44: 343-350.

103. Mabberley, D.J. (1999). Vitis x alexanderi Prince ex Jacques (Vitaceae), the first 'American Hybrid' grapes. Telopea 8: 377-379.

104. Mabberley, D.J. (1999). Edred John Henry Corner CBE. Biogr. Mems Fell. R. Soc. Lond. 45: 77-93.

105. Mabberley, D.J. (1999). The importance to Indopacific botany of Baron Dumont de Courset's Botaniste Cultivateur. Gard. Bull. Singapore 51: 309-317.

106. de Kok, R.P.J. \& Mabberley, D.J. (1999). Generic and intra-generic delimitation of Oxera Labill. (Labiatae). Kew Bull. 54: 257-264.

107. de Kok, R.P.J. \& Mabberley, D.J. (1999). A synopsis of Oxera Labill. (Labiatae). Kew Bull. 54: 265-300.

108. de Kok, R.P.J. \& Mabberley, D.J. (1999). The genus Faradaya (Labiatae). Blumea 44: 321-342. 
109. Mabberley, D.J. \& Moore, D.T. (1999). Catalogue of the holdings in The Natural History Museum (London) of the Australian botanical drawings of Ferdinand Bauer (1760-1826) and cognate materials relating to the Investigator voyage of 1801-1805. Bull. Brit. Mus. (Nat. Hist.), Bot. 29: $81-226$.

110. Steane, D.A., Scotland, R.W., Mabberley, D.J., Olmstead, R.G. (1999). Molecular systematics of Clerodendrum (Lamiaceae): ITS sequences and total evidence. Amer. J. Bot. 86: 98-107.

111. Mabberley, D.J. (2000). A tropical botanist finally vindicated. Gard. Bull. Singapore 52: 1-4.

112. Mabberley, D.J. (2000). The legacy of Flinders' Naturalist. Austral. Geographic 60: 46-63.

113. Mabberley, D.J. (2000). The Botanical Magazine and George Bond's drawings of Allan Cunningham's Australian plants. Curtis's Bot. Mag. n.s. 17: 226235.

114. Mabberley, D.J. (2000). Foreword. In: Chambers, N. (ed.) The letters of Sir Joseph Banks. A selection, 1768-1820, pp. xi-xii. London: Imperial College Press.

115. Pignatti-Wikus, E., Riedl-Dorn, C. \& Mabberley, D.J. (2000). Ferdinand Bauer's field drawings of endemic Western Australian plants made at King George Sound and Lucky Bay, December 1801 - January 1802. I. Rend. Fis. Acc. Lincei ser. 9, 11: 69-108.

116. Mabberley, D.J. (2001). Bidwill of the bunya-bunya. Curtis's Bot. Mag. n.s. 18: $31-46$.

117. Mabberley, D.J. (2001). Saved by Steudel: Grevillea manglesii revisited. Austral. Syst. Bot. Soc. Newslett. 105: 27-28.

118. Mabberley, D.J. (2001). Citrus re-united. Australian Plants 21: 52-55.

119. Mabberley, D.J., Jarvis, C.E. \& Juniper, B.E. (2001). The name of the apple. Telopea 9: 421-430.

120. Pignatti-Wikus, E., Riedl-Dorn, C. \& Mabberley, D.J., (2001). Ferdinand Bauer's field drawings of endemic Western Australian plants made at King George Sound and Lucky Bay, December 1801 - January 1802. II. Rend. Fis. Acc. Lincei ser. 9, 11: 201-244.

121. Mabberley, D.J. (2002). Ferdinand Bauer. In: Thomas, S. (ed.) The Encounter, 1802: Art of the Flinders and Baudin voyages, pp. 50-68. Adelaide: Art Gallery of South Australia.

122. Mabberley, D.J. (2002). A note on the Macaronesian Sideroxylon (Sapotaceae). Taxon 51: 179-180.

123. Mabberley, D.J. (2002). The Agathis brownii case (Araucariaceae). Telopea 9: $743-754$.

124. Mabberley, D.J. (2002). Potentilla and Fragaria (Rosaceae) re-united. Telopea 9: 793-801. 
125. Mabberley, D.J. (2002). Joseph Banks (1743-1820), Robert Brown (1773-1858). In: Aitken, R. \& Looker, L. (eds) The Oxford companion to Australian Gardens, pp. 71-73, 108-11. Melbourne: Oxford University Press.

126. Mabberley, D.J. (2002). The coming of the kauris. Curtis's Bot. Mag. n.s. 19: 252-264.

127. Mabberley, D.J. (2002). Limau hantu and limau purut: the story of lime-leaves (Citrus hystrix DC., Rutaceae). Gard. Bull. Singapore 54: 173-184.

128. Mabberley, D.J. (2002). The identity of Swietenia alternifolia (Mill.) Steud. ('Meliaceae'). Gard. Bull. Singapore 54: 253-255.

129. Mabberley, D.J. (2003). Robert Brown 200: introduction. Cunninghamia 7: 613-615.

130. Mabberley, D.J. (2003). 'Hardiness Zone 9' \& 'Plant Geography, Discovery and Classification'. In: Lord, T. (chief consultant) Flora. Volume 1, pp. 38-39 \& 50-51. London: Cassell.

131. Mabberley, D.J. (2003). Foreword. In: Webb, J.B., Botanical endeavour. Journey towards a Flora of Australia, pp. 3-4. Chipping Norton, NSW: Beatty \& Sons.

132. Mabberley, D.J. (2003). Prefácio. In: Fernandes, F.M. \& Mendonça de Carvalho, L., Portugal Botânico de A a Z. Plantas Portuguesas e exóticas, p.8. Lisbon: Lidel.

133. Mabberley, D.J. (2003). The type of Silene banksia (Caryophyllaceae). Blumea 48: 502.

134. Mabberley, D.J. (2003). New species of, and notes on, Chisocheton and Walsura (Meliaceae). Gard. Bull. Singapore 55: 189-200

135. Mabberley, D.J. \& Hartley, T.G. (2003). The identity of Picrella Baill. (Rutaceae) with a revision of the genus. Adansonia 25: 251-259.

136. Mabberley, D.J. (2004). More French 'firsts' ignored: Dumont de Courset's Le Botaniste Cultivateur. Taxon 53: 187-192.

137. Mabberley, D.J. (2004). Proposal to reject the name Fraxinus tetragona Dum. Cours. (Oleaceae). Taxon 53: 209.

138. Mabberley, D.J. (2004). Taxonomy. In: Encyclopedia of Life Sciences, vol. 12, pp. 1599-1602. London: Nature Publishing Group.

139. Mabberley, D.J. (2004). Robert Brown 200: Introduction. Telopea 10: 497-498.

140. Mabberley, D.J. (2004). European discovery, classification and naming. In: Sripathy V. (ed.) Red Cedar in Australia, pp. 23-41, 108-110. Sydney: Historic Houses Trust of New South Wales.

141. Mabberley, D.J. (2004). Foreword. In: Large, M.F. \& Braggins, J.E., Tree-ferns. Portland, Oregon \& Cambridge, UK: Timber Press.

142. Mabberley, D.J. (2004). Ferdinand Bauer, John Joseph Bennett, John Carne Bidwill, Robert Brown, Patricia Bury, William Griffith, Francis Hamilton, William Herbert, William Jack, Aylmer Bourke Lambert, Richard Anthony Salisbury. In: Lightman, B. (ed.) Dictionary of Nineteenth-century British scientists, various pp. Bristol: Thoemmes Continuun. 
143. Mabberley, D.J. (2004). A key to Dysoxylum (Meliaceae) in Australia, with a description of a new species from Far North Queensland. Telopea 10: $725-729$.

144. Mabberley, D.J. (2004). Foreword. In: Moore, D., The botanist William Curtis (1746-1799) and St Mary's Battersea, pp. 3-4. Battersea, London: St Mary's Church.

145. Mabberley, D.J. (2004). William Aiton, William Townsend Aiton, Alexander Anderson, Valentine Bartholomew, Robert Brown, Priscilla Bury, Arthur Harry Church, Edred John Henry Corner, James Cuninghame, Johann Jakob Dillenius, Peter Good, Mary Harrison, Arthur Henfrey, Robert ('Robin') Hill, John Hope, James Naesmyth, David Nelson, George Sherriff, [with D.E. Evans] Walter Stiles, Sydney Vines, Edmund Warburg, Richard Warner, Ernest Wilson. In: Matthew, H.C.G. \& Harrison, B.H. (eds) Oxford Dictionary of National Biography, various pp. Oxford: Oxford University Press.

146. Mabberley, D.J. (2004). Foreword. In: Cooper, W. \& Cooper, W.T., Fruits of the Australian tropical rainforest, pp. v-vi. Melbourne: Nokomis.

147. Mabberley, D.J. \& de Kok, R.P.J. (2004). Labiatae. Flore de la NouvelleCalédonie et Dépendances 25: 20-141.

148. Mabberley, D.J. (2004). Vitaceae. Flore de la Nouvelle-Calédonie et Dépendances 25: $142-152$.

149. Mabberley, D.J. (2004). Citrus (Rutaceae): a review of recent advances in etymology, systematics and medical applications. Blumea 49: 481-498.

150. Mabberley, D.J. \& Dixon, D. (2004). Proposal to reject the name Ficus novaevalliae Dum. Cours. (Moraceae). Taxon 53: 208.

151. Mabberley, D.J. \& Stuessy, T.F. (2004). Editorial. Taxon 53: 1-2.

152. Ramón-Laca, L. \& Mabberley, D.J. (2004). The ecological status of the carobtree (Ceratonia siliqua L., Leguminosae) in the Mediterranean. Bot. J. Linn. Soc. 144: 431-436.

153. Goldblatt, P. \& Mabberley, D.J. (2005). Belamcanda included in Iris, and the new combination, I. domestica (Iridaceae: Irideae). Novon 15: 128-132.

154. Mabberley, D.J. (2005). Foreword [and chief consultant]. In: Usher, C., White, J. \& Ridsdale, C., Dorling Kindersley Eyewitness Companions - Trees. New York: DK Publishing

155. Mabberley, D.J. (2005). Robert Brown's later career. In: Wege, J., George, A., Gathe, J., Lemson, K. \& Napier, K. (eds) Matthew Flinders and his Scientific Gentlemen: the Expedition of HMS Investigator to Australia, 1801-05, pp. 165-171. Perth: Western Australian Museum

156. Mabberley, D.J. \& Clarkson. J.R. (2005). Under the watchful eye of centinels: Robert Brown at the Pennefather River. Royal Geographical Society of Queensland, Geographical Monograph No.10: 109-117.

157. Mabberley, D.J. \& Kiew, R. (2005). A particularly important de Alwis watercolour: Citrus halimii. Gardenwise July 2005: 30. 
158. Mabberley, D.J., Gravendeel, B. \& Van Der Meijden, R. (2005). Een andere indeling van Plantenfamilies: nieuwe inzichten uit DNA-onderzoek. In: van der Meijden, R., Heukels' Flora van Nederland, 23 $3^{\text {rd }}$ edition, pp. 1219. Groningen/Houten: Wolters-Noordhoff.

159. Beattie, G.A.C., Hofford, P., Mabberley, D.J., Haigh, A.M., Bayer, R. \& Broadbent, P. (2006). Aspects and insights of Australia-Asia collaborative research on hunaglongbing. In: Proceedings of the International Workshop for Prevention of citrus greening disease in severely affected areas, pp. 47-64. Tokyo: Multilateral Research Network for Food \& Agricultural Safety, Japanese Ministry of Agriculture, Forestry \& Fisheries.

160. Mabberley, D.J. \& Moore, D.T. (2007). Some background to Robert Brown's Australian botanical work: his manuscripts, publications and plant-names. Austral. Syst. Bot. Soc. Newslett. 133: 47.

161. Mabberley, D.J., Pannell, C.M., Edmonds, J.M. \& Sing, A.M. (2007). Meliaceae. In: Soepadmo, E., Saw, L.G., Chung, R.C.K. \& Kiew, R. (eds) Tree Flora of Sabah \& Sarawak, vol. 6, pp. 17-218. Kuala Lumpur: Forest Research Institute Malaysia.

162. Mabberley, D.J., Pignatti-Wikus, E. \& Riedl-Dorn, C. (2007). An extinct tree 'revived'. Curtis's Bot. Mag. 24: 190-196.

163. Hua, P., Mabberley, D.J., Pannell, C.M., Edmonds, J.M. \& Bartholomew, B. (2008). Meliaceae. In: Wu, Z.Y. \& Raven, P.H. (eds) Flora of China, vol. 11, pp. 111-131. Beijing: Science Press; and St Louis: Missouri Botanical Gardens Press.

164. Muellner, A.N. \& Mabberley, D.J. (2008). Phylogenetic position and taxonomic disposition of Turraea breviflora Ridl. (Meliaceae), a hitherto enigmatic species. Blumea 53: 607-616.

165. Zhang, D. \& Mabberley, D.J. (2008). Citrus. In Wu, Z.Y. \& Raven, P.H. (eds) Flora of China, vol. 11, pp. 90-96. Beijing: Science Press; and St Louis: Missouri Botanical Gardens Press.

166. Bayer, R.J., Mabberley, D.J., Morton, C., Miller, C.H., Sharma, I.K., Pfeil, B.E., Rich, S., Hitchcock, R., Sykes, S. (2009). A molecular phylogeny of the orange subfamily (Rutaceae: Aurantioideae) using nine cpDNA sequences. Amer. J. Bot. 96: 668-685.

167. Mabberley, D.J. (2009a). Exploring Terra Incognita. Science 324: 472.

168. Wearn, J.A. \& Mabberley, D.J. (2009). Iberis violacea R. Br. (Brassicaceae). Fl. Medit. 19: 261-266.

169. Mabberley, D.J. (2010). The species of Citrus with pinnate leaves. Blumea 55: 73-74.

170. Mabberley, D.J. (2010). The international significance of Sydney's kauri collection. Int. Dendrol. Soc. Year Book 2009: 103-108.

171. Mabberley, D.J. (2010). Meliaceae. In: Kubitzki, K. (ed.) Families and Genera of Vascular Plants, vol. 10, pp 185-211. Berlin: Springer.

172. Mabberley, D.J. (2010). Peter Placito, naturalist. Wadham College Gazette 2010: 162-163. 
173. Yuan, Y., Mabberley, D.J., Steane, D.A. \& Olmstead, R.G. (2010). Further disintegration and redefinition of Clerodendrum (Lamiaceae): implications for the understanding of the evolution of an intriguing breeding strategy. Taxon 59: 125-133.

174. Hardwick, K.A. et al. [35 authors incl. Mabberley, D.J.] (2011). The role of botanic gardens in the science and practice of ecological restoration. Conserv. Biol. 25: 265-275.

175. Mabberley, D.J. (2011). Sixty years of Taxon. Taxon 60: 3.

176. Mabberley, D.J. (2011). The role of a modern botanic garden: the evolution of Kew. Plant Divers. Res. 33: 31-38.

177. Mabberley, D.J. (2011). Foreword. In: Carter, S., Lavranos, J.J., Newton L.E. \& Walker, C.C., Aloes, p. 6. Kew: Royal Botanic Gardens, Kew.

178. Mabberley, D.J. (2011). Foreword. In: Pienaar, K. \& Smith, G.F., The Southern African What flower is that? $5^{\text {th }}$ ed., p. 7. Cape Town: Struik.

179. Mabberley, D.J. (2011). A note on some adulatory botanical plates distributed by Sir Joseph Banks. Kew Bull. 66: 475-477.

180. Mabberley, D.J. \& Hopper, S.D. (2011). 'The Queen of Botany': Charlotte and the royal gardens at Kew. In: Gahrau, M. (compiler) Festschrift anlässlich des 250sten Jubiläums der Krönung von Sophie Charlotte, Prinzessin zu Mecklenburg-Strelitz zur Königin von Großbritannien, pp. 47-53. Schwerin.

181. Wearn, J.A. \& Mabberley, D.J. (2011). Clerodendrum confusion - redefinition of, and new perspectives for, a large Labiate genus. Gard. Bull. Singapore 63: $119-124$.

182. Wearn, J.A. \& Mabberley, D.J. (2011). Clerodendrum (Lamiaceae) in Borneo. Syst. Bot. 36: 1050-1061.

183. Wearn, J.A. \& Mabberley, D.J. (2011). Clerodendrum L. In: Soepadmo, E., Saw, L.G., Chung, R.C.K. \& Kiew, R. (eds) Tree Flora of Sabah \& Sarawak, vol. 6, pp. 33-37. Kuala Lumpur: Forest Research Institute Malaysia.

184. Mabberley, D.J. (2012). Harry Hay. Herbertia 65: 22.

185. Wearn, J. \& Mabberley, D.J. (2012). Clerodendrum conundrums. The Plantsman 11: $146-153$.

186. Mabberley, D.J. (2013). Whither Australasian plant systematics? Austral. Syst. Bot. Soc. Newslett. 153: 32-38.

187. Mabberley, D.J. (2013). Meliaceae [excl. Aglaia.]. Flora of Australia 26: 1-42.

188. Mabberley, D.J. (2013). Rutaceae (Group 4 [Aurantioideae]). Flora of Australia 26: 488-502.

189. Mabberley, D.J., Pannell, C.M. \& Edmonds J.M. (2013). Meliaceae. In: Kiew, R. Chung, R.C.K., Saw, L.G. \& Soepadmo, E. (eds) Flora of Peninsular Malaysia, ser. 2, vol. 4, pp. 47-267, tt. 9-23. Kuala Lumpur: Forest Research Institute Malaysia.

190. Wearn, J.A, Chase, M.W., Mabberley, D.J. \& Couch, C. (2013). Utilizing a phylogenetic plant classification in systematic arrangements in botanic gardens and herbaria. Bot. J. Linn. Soc. 172: 127-141. 
191. Cuong, N.T., Hoan, D.T. \& Mabberley, D.J. (2014). Munronia petiolata (Meliaceae), a new species from Vietnam. Blumea 59: 139-141.

192. Mabberley, D.J. (2014). Foreword. In Kanellos, T., Out of the past: views of Adelaide Botanic Garden, pp. 8-11. Adelaide: Botanic Gardens of Adelaide.

193. Mabberley, D.J. \& Moore, D.T. (2014). (2315-2316) Proposals to reject the names Hylococcus and H. sericeus (Picrodendraceae). Taxon 63: 944-945.

194. Mabberley, D.J. \& Noltie, H.J. (2014). A note on Valeriana jatamansi Jones (Caprifoliaceae s.1.). Blumea 59: 37-41.

195. Mabberley, D.J. (2015). (2351) Proposal to reject the name Rhytidea bicolor Lindl. (Asparagaceae). Taxon 64: 384-385.

196. Mabberley, D.J. (2015). The identity of Rhytidea bicolor Lindl., a geophyte collected in California by William Lobb. Madroño 62: 137-138.

197. Mabberley, D.J. (2015). Rapid publication in the mid-nineteenth century: John Lindley's 'New Plants' column in the Gardeners' Chronicle. Taxon 64: 841-844.

198. Mabberley, D.J. (2015). Botanic Gardens, herbaria and research: the UK experience. Ethiop. J. Biol. Sci. 13: 103-113.

199. Mabberley, D.J. (2016). La enigmática carta de colores de Tadeo Haenke. Matador 21: 97.

200. Mabberley, D.J. \& Kodela, P.G. (2015). Lectotypification of Citrus cavaleriei H.Lév. ex Cavalerie (Rutaceae: Aurantioideae). Telopea 18: 115-119.

201. Mabberley, D.J. (2016). The typification of Murraya, M. exotica and $M$. paniculata (Rutaceae): its significance for the world citrus industry. Taxon 65: 366-371.

202. Mabberley, D.J. (2016). (2433) Proposal to conserve Chalcas paniculata (Rutaceae) with a conserved type. Taxon 65: 394-395.

203. Mabberley, D.J. (2016). On the identity of Rumphia L., the last remaining puzzle in Van Rheede's Hortus malabaricus (1678-1693). J. Jap. Bot. 91: 326329.

204. Mabberley, D.J. [as member of Angiosperm Phylogeny Group] (2016). An update of the Angiosperm Phylogeny Group classification for the orders and families of flowering plants: APG IV. Bot. J. Linn. Soc. 181: 1-20.

205. Knapp, S. et al. [18 authors incl. Mabberley, D.J.] (2016). Proposal to replace Division III of the International Code of Nomenclature for algae, fungi, and plants. Taxon 65: 661-664.

206. Knapp, S. et al. [18 authors incl. Mabberley, D.J.] (2016). Report of the Special Committee on By-laws for the Nomenclature Section. Taxon 65: 665-669.

207. Wearn, J.A. \& Mabberley, D.J. (2016). Citrus and orangeries in northern Europe. Curtis's Bot. Mag. 33: 94-107.

208. Wahlert, G.A., Phillipson, P.B., Mabberley, D.J. \& Lowry P.P. (2016). Grewia hispidissima Wahlert, Phillipson \& Mabb., sp. nov. (Malvaceae, Grewioideae): a new species of restricted range from northwestern Madagascar. Adansonia 38: 117-121. 
209. Mabberley, D.J. (2017). Foreword. In: Watt, A., Robert Fortune: a plant hunter in the Orient, pp. 6-7. Kew: Royal Botanic Gardens Kew.

210. Mabberley, D.J. (2017). A note on the tonka bean and William Forsyth junior's 'A botanical nomenclator' (1794). Blumea 62: 87-89.

211. Mabberley, D.J. (2017). (2558) Proposal to conserve Murraya, nom. cons., against the additional name Chalcas (Rutaceae). Taxon 66: 1229-1230.

212. Mabberley, D.J \& Al-Shehbaz, I.A. (2017). What is Philip Miller's "Perennial Moonwort”, Lunaria perennis (Brassicaceae/Cruciferae)? Novon 25: 414418.

213. Mabberley, D.J. \& Capuron, R. (2017). Two nomina nova in Malagasy Grewia L. (Malvaceae-Grewioideae). Telopea 20: 85-88.

214. Mabberley, D.J. (2018). A note on the chestnut vine and Séraphin Mottet's 'Dictionnaire d'Horticulture et Jardinage' (1892-99). Blumea 62: 240-244.

215. Mabberley, D.J. (2018). An inconvenient truth? Notes on Australian plants in Persoon's Synopsis Plantarum (1806-7). Austral. Syst. Bot. Soc. Newslett. 174: 7-10.

216. Mabberley, D.J. (2018). The orthographic significance of the Latin name for the 'Norfolk Island Hibiscus' (Malvaceae). Taxon 67: 792-793.

217. Mabberley, D.J. (2018). Botany of citron (Citrus medica L.) and the citrus tribe. In: Goldschmidt, E.E. \& Bar-Joseph, M. (eds) The etrog citron (Citrus medica L.): tradition and research, pp. 83-107. Jerusalem: Mosad Harav Kook.

218. Mabberley, D.J. (2018). A Persian lilac for the windowsill. Plantsman n.s. 17: 84-85.

219. Mabberley, D.J. (2019). 'Alexander' and 'Isabella', the first American hybrid grapes. Plantsman n.s. 19: 36-37.

220. Mabberley, D.J. \& Pickering, H. (2019). The first herbarium collection from the south Arabian coast? Arch. Nat. Hist. 46: 119-123.

221. Wearn, J.A. \& Mabberley, D.J. (2019). Clerodendrum, Rotheca, and Volkameria. In: Bramley, G. et al., Lamiaceae, Flora Malesiana, ser. I, Seed Plants, vol. 23, pp. 90-157, 337-339, 422-423. Leiden: Foundation Flora Malesiana.

222. Mabberley, D.J. \& Wearn, J.A. (2019, in press). Citrus. Flora of North America.

223. Mabberley D.J. \& Moore, D.T. (with the assistance of J. Wajer) (2019, in press [November]). The Robert Brown Handbook: a guide to the life and work of Robert Brown (1773-1858), Scottish botanist. Regnum Veg. 160. Glashütten: Koeltz Botanical Books.

224. Mabberley, D.J. (2019, in press [November]). Botanical Revelation: preDarwinian European encounters with the Australian Flora The Peter Crossing Library. Sydney: NewSouth.

225. Maslin, B., Thomson, L. \& Mabberley, D.J. (2019, in press). Acacia $\times$ mangiiformis (Leguminosae: Mimosoideae), a new hybrid wattle of commercial importance in Asia. Telopea. 